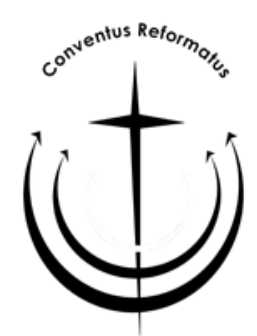

\title{
What are the key characteristics of a Christian life? A comparison of the ethics of Calvin to that of Augustine and their relevance today
}

\author{
J.H. van Wyk \\ North-West University \\ Potchefstroom Campus \\ POTCHEFSTROOM \\ E-mail: amievw@intekom.co.za
}

\begin{abstract}
What are the key characteristics of a Christian life? A comparison of the ethics of Calvin to that of Augustine and their relevance today
\end{abstract}

Augustine and Calvin are two of the greatest (western) theologians of all times and it is illuminating and inspiring to investigate what they have to teach as far as Christian life is concerned. Augustine never wrote a work on Christian ethics in the modern sense of the word but from his many writings we can easily deduce what the key characteristics are. He accepted the natural virtues of philosophers (prudence, fortitude, temperance and justice) but subordinated them to the "infused virtues" of faith, hope and love. Special attention was also paid to inter alia happiness, humility and truth. Calvin, on the other hand, although following Augustine in many aspects of theology, rejected the virtue ethics of the Greek philosophers and developed a Christological ethics within the broader context of pneumatology. The key characteristics of a Christian life are self-denial, cross-bearing and meditation on the future life - and of course the correct enjoyment of the present life. Although we appreciate much of what the two church fathers have to say, we live in a totally different world context today, facing challenges of far greater proportions, like economical uncertainty, political instability and an immense ecological crisis. Morality is challenged today as never before in world history. Today we have to rethink the relevance of Christian life not only from an 
individual personal perspective but also in terms of broader social Christian ethics.

\section{Opsomming}

\section{Wat is die hoofeienskappe van 'n Christelike lewe? 'n Vergelyking van die etiek van Calvyn met dié van Augustinus en hulle relevansie vir vandag}

Augustinus en Calvyn is twee van die grootste (westerse) teoloë van alle tye en dit is verhelderend en inspirerend om ondersoek in te stel na wat hulle oor die Christelike lewe te sê het. Augustinus het nooit 'n boek oor die Christelike etiek in die moderne sin van die woord geskryf nie, maar van sy talle geskrifte kan maklik afgelei word wat die hoofkenmerke daarvan is. Hy het die natuurlike deugde van die filosowe (verstandigheid, dapperheid, matigheid en regverdigheid) aanvaar, maar dit ondergeskik gestel aan die "ingestorte deugde" van geloof, hoop en liefde. Besondere aandag word ook bestee aan onder andere gelukkigheid, nederigheid en waarheid. Alhoewel Calvyn Augustinus in talle aspekte van die teologie navolg, het hy, aan die ander kant, die deugde-etiek van die Griekse filosowe verwerp en 'n Christologiese etiek ontwerp binne die groter konteks van die pneumatologie. Die hoofeienskappe van 'n Christelike lewe bestaan uit selfverloëning, kruisdra en oordenking van die toekomstige lewe - en natuurlik die regte gebruik van die huidige lewe. Alhoewel ons groot waardering kan hê vir dit wat die twee kerkvaders te sê het, leef ons vandag in 'n totaal ander wêreldkonteks en staar ons probleme van veel groter omvang in die gesig, soos ekonomiese onsekerheid, politieke onstabiliteit en 'n enorme ekologiese krisis. Moraliteit word vandag uitgedaag soos nog nooit tevore in die wêreldgeskiedenis nie. Vandag moet ons die relevansie van die Christelike lewe heroorweeg nié net vanuit die perspektief van individuele persoonlike etiek nie, maar ook in terme van 'n breër sosiale Christelike etiek.

\section{Introduction}

Two of the greatest theologians that lived were Aurelius Augustine (354-430) and John Calvin (1509-1564) whose 5th centenary we celebrated in 2009. It is said that "no figure in Christianity between Paul and Luther has excercised greater influence in theology and church than Augustine" (Küng, 1995:288). ${ }^{1}$ We may add: between

1 Somebody once said that western philosophy is nothing more than footnotes to Plato, and likewise it can be said "that theology in western Christianity has been a series of footnotes to Augustine" (Williams, 1955:4). 
Paul and Calvin. On the other hand, it is a well-known fact that Calvin was profoundly influenced by Augustine (Lane, 1999:38), ${ }^{2}$ especially with regard to dogmatics (sin and grace) and that he quoted Augustine 410 times in his Institutes of 1559 (Lange van Ravenswaay, 1990:105). No church father is as frequently quoted by Calvin as Augustine (Mooi, 1965:262). The question arises whether this is also true as far as ethics is concerned. Did Calvin also follow his mentor in ethics?

It is generally accepted that dogmatics deals with "what we believe" while ethics is all about "what we do". This distinction is not nuanced enough because not all human activities are ethical activities, but for the purpose of this presentation I will use this general distinction.

Christianity is about doctrina and vita, doctrine and daily life, orthodoxy and orthopraxy, and they form an inseparable unity. We have to believe the correct things and we have to do the right things. The one cannot go without the other and they are inseparably intertwined.

"A tree is recognized by its fruit", Christ taught (Matt. 12: 33). And "not everyone who says to me, 'Lord, Lord,' will enter the kingdom of heaven, but only he who does the will of my Father who is in heaven" (Matt. 7:21).

The same message resounds in the letters of Paul, in Romans for example, and also in Galations 5:6 where he writes that "the only thing that counts is faith expressing itself through love." James 2:1426 also very closely relates faith and deeds. John writes to the congregation of Ephesus that keeping to the pure doctrine is not enough when the love for Christ (and Christians) are lacking (Rev. 2: 1-7).

There is no question that Augustine and Calvin were very keen on accepting and protecting the true doctrine. What did they teach about Christian life? Did Calvin follow Augustine in this regard? And how relevant is their teaching for us today?

I start with an exposition of the ethics of Augustine followed by that of Calvin.

2 "Calvin held Augustine in the highest regard", and: "Calvin's teaching was to a considerable extent ... a revival of Augustinianism ..." (Lane, 1999:38). Cf. also Han (2008:70-83). 


\section{De beata vita: Augustine}

When one investigates the ethics of Augustine, different approaches are possible. One could highlight his views on various ethical topics like marriage and sexuality (Van Wyk, 2002a:327-348), politics (Van Wyk, 2001a:133-152) and war (Van Wyk, 1984:58-61). Or one could focus on the key features of his ethics like happiness, humility, truth and love. 3 In this approach I will focus on the key features without ignoring the topics. 4

Augustine never wrote a handbook on ethics in the modern sense of the word. As a young theologian he reflected on De beata vita ( $b$. vita) and De moribus ecclesiae catholicae et de moribus Manichaeorum (mor.) and 40 years later gave a summary of the divine biblical precepts and prohibitions in Speculum (427). In many of his other books, commentaries, sermons and letters many suggestions and reflections on ethical matters are found. To a certain extent we find Augustine's fully developed ethics in his magnum opus De civitate Dei (civ. DeI) - as Carney (1991:23) remarks.

Although Augustine accepted the natural virtues discussed by philosophers like prudence, fortitude, temperance and justice, he subordinated them to the three "infused virtues" namely faith, hope and love (see mor. 15.25; ${ }^{5}$ cat. rud. 17.27). ${ }^{6}$ Laverre (1999:872) states: "These seven virtues together with the commandments of God and the Beatitudes of the New Testament constitute a seven-stage plan for Christian living in which the virtues play the decisive role." (Cf. Switalski, 1946.)

3 Of course there are more, for example freedom and peace. Cf. also Reul (1928).

4 For the ethics of Augustine see inter alia the following books: Mausbach (1909), Reul (1928), Switalski (1946), Babcock, (1991) and Wetzel (1992).

For shorter studies see the following: Roland-Gosselin, 1930:225-248; Bigham \& Mollegen, 1955:371-397; Laverre, 1999:871-874; Schlabach \& Fitzgerald et al., 1999:320-330; Kent, 2001:205-233.

5 For clarity on the way of referring to the works of Augustine, see footnote 30 on p. 65.

6 Cf. also Bigham and Mollegen (1955:19-25) and Laverre (1999:872). Wetzel, on the other hand, is of the opinion that Augustine heavily depends on the stoic ethics of virtue, autonomy and happiness when he states: "Augustine's sensibilities in ethics are fundamentally Stoic" (Wetzel, 1992:11, 54). 


\subsection{Happiness}

I start with the notion of happiness, not because it is the most important characteristic, but because Augustine reflected on it from a very early stage as a young theologian. Marrou (1981:151) even refers to it as a central problem in the thought of Augustine. As Cicero had done in his Hortentius, Augustine mentioned many times that all persons strive to be happy (b. vita. 2.10; conf. 10.20-30; sermo-a. 1.1; sermo-c. 150). Morality has to do with the way people want to live a happy life (mor. 5.8).

The central question during Augustine's short stay with friends and his mother in Cassiciacum near Milan after his conversion, was what a happy life is and where do we find it (cf. Lancel, 2002:176). 7 Against the sceptics Augustine argued that they would never find happiness, because they denied the existence of truth. Only those who possess the eternal and graceful God can be happy (b. vita. $2.11 ; 3.19)$. True happiness exists in knowing God and Jesus Christ (b. vita. 4.33, 34). 8 Unhappy are those who know everything, may be all facts, but not God (conf. 5.4). 9

In the first ten books of his De civitate Dei Augustine refuted the pagan approach that happiness in and after this life is possible by serving idols. In one of his sermons he prayed that God must give us happiness, not through earthly possessions, which can be lost, but through Him whom we never can lose (sermo-b. 113).

In the end the highest happiness is found in eternal life where there is no fear and no delusion (sermo-b. 113).10 Ultimately a restless heart can only come to rest in God (conf. 1.1). 11

Augustine did not advocate a cheap form of eudaemonism (i.e. happiness is the aim and measure of virtue; happiness is the supreme

7 "Quid sit beata vita".

8 Cf. also Galvao (1986-1994:624-638) and Couvee (1947; Couvee argues that Augustine in the end overcame the philosophic influences).

9 Augustine rejects the idea that happiness rests on virtue (paganism) or freedom (Pelagianism) (Wetzel, 1992:123). mortality and eternal life. 
good). 12 Happiness without piety and adoration of the true God is cheap (civ. Dei. 4.23). Therefore in his sermons and writings the bishop would always warn against the evils of this world like gambling, the theatre, the pub, a brothel, abuse of liquor, greed, fraud, adultery, fornication and astrology (cat. rud. $7.11 ; 16.25 ; 25.48 ; 27.55)^{13}$

A happy life is a life of close fellowship with God and the neighbour.

\subsection{Humility}

Another very important feature of Augustine's ethics is humility. Humility is a fundamental virtue, the virtue of all virtues (cf. reg.). ${ }^{14} \mathrm{It}$ is correctly observed that Augustine's great discovery was the significance of humility, as opposed to the sin of pride, and that happiness can only be experienced where reason submits itself to faith and the will to grace (Gilson, 1960:227). Happiness starts with humility (s. Dom. mon. 1.10). For Augustine pride is the beginning of all sin and the beginning of pride is infidelity towards God (s. Dom. mon. 1.32; sermo-d. 198). Pride is the origin and highest expression of $\sin$ (Van Bavel, 1970:43). Pride, as the perverted imitation of God, is the beginning of all sin and it ends up in abuse of power (libido dominandi) (Markus, 1988:xvii). Perverted self-love, based on pride, is the fundamental disorder of the individual and society (Markus, 1988:xviii).

Burns (1991:82) postulates the following: "For Augustine, then, pride is the root form of evil, separating the self from God and playing itself out in claims to moral self-suffiency, to religious superiority, and to political domination."

It is intriguing that a man who was so well-known and famous in his own time - according to Jerome (TeSelle, 1970:341; Rist, 1999:290) - put so much emphasis on the notion of humility. This was only

12 Augustine rejects the hedonism of the Epicureans as well as the apathetic approach of the Stoics (Roland-Gosselin, 1930:229-231).

13 The bishop had no objections against the (moderate) use of wine, see Possidius (1988:91-92; Vita 22.2).

14 Cf. also Mayer (2006:443-456; Mayer mentions that "humilitas" is derived from "humus" which means "surface of the earth", "down to earth"), Van der Meer (1949:273), Roland-Gosselin (1930:246) and in extenso Schaffner (1959). O'Donnell (2005:36), on the other hand, considers the Confessiones not as a book of humility but of personal aggrandisement. 
possible, because Augustine imitated Christ who humbled Himself for us.

\subsection{Truth}

Another moral value that was held in high esteem by the church father was truth. A life of beatitude (to him) implies a life of joy in truth, which means a life of joy in God (conf. 10.23). Truth and happiness form an inseparable unity: add truth to your life and you will find happiness; only the truth can make one happy (cf. Burnaby, 1938:153; Gilson, 1960:3). Without faith nobody will discover truth.

From his early writings till his more mature reflections Augustine rejected scepticism and discovered the summa veritas in the Word of God presented to us by the Holy Spirit (conf. 10.24; 13.31; mor. 29; cf.also Studer, 2006:411-455).

The bishop was very much outspoken against any form of lying, without any exception whatsoever, as can clearly be seen from his studies on De Mendacio (394) and Contra Mendacium (420). 15 This radical (and perfectionist) standpoint prevented him from developing any notion of a so-called "necessary lie" (or "crisis truth") which we experience in critical situations in a sinful world (cf. Van Wyk, 2001a:82-86). Augustine's view on truth was greatly influenced by Neo-Platonism, but it is also true to say that in his later development he followed a more theological and Christological approach in this regard.

\subsection{Love}

A last, and most important, aspect that I would like to mention is Augustine's treatment of the notion of love.

Augustine is described as doctor gratiae and doctor pacis, but in a very real sense he can also be referred to as doctor caritatis. This notion appears in almost all his writings, most explicitly in his Enchiridion ad Laurentium de fide spe et caritate (ench.) and In epistulam Joannis ad Parthos tractatus (ep. Jo.).

For Augustine love is the highest value and the biggest gift. The Bible teaches nothing else than love (caritas) and condemns desire (cupiditas) and pride (superbia), which results in the lust for power 
(libido dominandi) (doc. Chr. 3.10.15; cf. Mausbach, 1909,1:222263). Love can be described as the hermeneutical key to a correct understanding of the Bible. If someone reads the Bible and does not discover what love really means, then he has not discovered what the Bible is all about (doc. Chr. 3.15.23).

From the very beginning catechumens have to know that the main reason for the advent of Christ lies in the fact that God wanted to show us his love (cat. rud. 4.7). Love is defined as "the motion of the soul toward enjoyment of God for his own sake, and the enjoyment of one's self and of one's neighbour for the sake of God" (doc. Chr. 3.10.16). Our highest bliss consists of the enjoyment of the triune God (trin. 1.8.18; cf. Mausbach, 1909,1:168-221). The good (people) use the world that they may enjoy God; the wicked, on the contrary, use God that they may enjoy the world (civ. Dei. 15.7).

The church father prefers to speak of an ordered love (ordo caritatis) (cf. Torchia, 1993:263-276). "The peace of things is the tranquility of order. Order is the distribution which allots things equal and unequal, each to its own place" (civ. Dei. 19.13). First comes the love for God and then the love for humans (civ. Dei. 15.22). We should never love the Absolute (God) in a relative way and what is relative (humans) in an absolute way. Love is the weight which orders life and keeps it in balance (conf. 13.9). True religion does not exist in anger, nepotism and hate, but in love (including love for the enemy) and the imitation of God (sermo-a. 7.4; 9.3). There is no more difficult assignment than to love your enemy (sermo-a. 7.4).

It is clear that for Augustine love takes priority (ench. 117). If you want to know whether a person is good, do not ask about his faith or his hope, but what he loves. Because a person who loves in the correct way, will also believe and hope in the correct way, while a person who does not love correctly, will believe in vain, even if the contents of faith are correct and also hope in vain, even if the object of his hope is real (ench. 117).

According to Augustine there are two cities (or kingdoms) on earth, the civitas Dei and the terrena civitas, and the difference between the two is revealed in two ways of life and two ways of love: love for God or love for the self.

Two cities have been formed by two loves: the earthly of love of self, even to the contempt of God; the heavenly by the love of God, even to the contempt of self. The former, in a word, glories in itself, the latter in the Lord (civ. Dei. 14.28). 
Therefore citizens of the city of God only make use (uti) of earthly things, for they can only enjoy (frui) God and his kingdom. 16

Augustine's sermon commentary on 1 John can be described as a song of praise on love, a song with many variations as can be seen from the following quotations from ep. Jo.: a man is as he loves (2.14); love is the beauty of the soul (10.9); love is the completion of all our work; if we have reached love, we shall find rest (10.4); love, and you will do nothing else than good (10.7); the practising of love, her strength, her flourishing, her fruit, her beauty, her charm, her nourishment, her drink, her food, her embracement, know no satisfaction (10.7).

It is within this context that the bishop turns to the schism between the Catholic and Donatist churches which developed during the fourth century and tragically divided the churches of Christ in North Africa (cf. Frend, 1952; Van Wyk, 2002b:26-32). There were no fundamental confessional differences between the two "denominations", although the Donatists strongly emphasised the holiness of the church. Schismatics tend to view themselves as better and more advanced and holier Christians than those who belong to the "mother church". Augustine, stressing the unity and catholicity of the church of Christ, and that the church is a corpus permixtum, argued that those who break the unity (albeit with good intentions) act without love. "Of the Donatists, for example, you cannot possibly say that they have love, because they have broken the unity of the church" (ep. Jo. 6.2).

It is also within this context that Augustine used his famous dictum: Love and do what you will (dilige et quod vis fac) (ep. Jo. 7.8). Christians must love everybody, even their opponents, yes, their enemies. This also applies to Catholic Christians in their relationship with Donatist Christians (TeSelle, 1991:151).

As far as ecclesiology is concerned, in our current situation the church father speaks loud and clear to us who feel very comfortable in a (ongoing and never-ending) situation of church separation and division. The New Testament knows only of the one church of Christ, situated in many villages, towns and cities and nothing of divided and opposing churches and "denominations". The New Testament calls upon us to speak the truth in love (Eph. 4:15). When love Limb (2006:183-197). 
disappears, even if there is a strong pursuit of truth, the church has no future (Rev. 2:1-7).

Eschatology plays a very important role in the theology and ethics of the church father as can be seen from his De civitate Dei. Christian life must be orientated towards and focused on the future life and the consummation of the kingdom of God:

There we shall rest and see, see and love, love and praise. This is what shall be in the end without end. For what other end do we propose to ourselves than to attain to the kingdom of which there is no end? (civ. Dei. 22.30.)

\subsection{Comments}

The question arises whether Augustine himself lived up to the high standard of love which he emphasised so much? Three questions arise in this regard: his view on war, the use of state power and his marriage ethics (including his relationship with his concubine).

Augustine was (probably) the first theologian to develop the theory of a just war (bellum justum) (cf. Van Wyk, 1984:58-61; Langan, 1991:168-189; Holmes, 1999:323-344; O'Donovan, 2003). The three preconditions are: legitima auctoritas, justa causa and recta intentio, with emphasis on the latter. However, it is unclear how the principle of love could be kept intact in a situation of war. It is obvious "that peace is the end sought for by war; for every man seeks peace by waging war, but no man seeks war by making peace" (civ. Dei. 19.12). What is not obvious is what happens to the commandment of love in a war situation. Is it morally acceptable for Christians to kill other Christians - even with a recta intentio?

The second question arises from the fact that the bishop in the end - after ten years of discussions, debates and writings with and against the Donatists - approved of state enforcement against them to join the Catholic Church. Although Augustine stated in his Retractationes (retr. 2.5) that it was not his desire that the schismatics be forced back into the church, his approach as a whole seems to have given too much power to the state in church affairs.

Thirdly, Augustine's marriage ethics belongs to the most problematic part of his ethics, because of his degrading of the physical and sexual dimension of love in marriage life. With his strong emphasis on marriage life for the sake of procreation (proles), Augustine failed to arrive at a positive view on sexuality (and sexual desire) as a dimension of love in marriage (venialis culpa) (cf. Van Wyk, 2002a: 
327-348). Was this one of the reasons why he later distanced himself from his concubine with whom he had lived for fourteen years, whose name he never mentioned? Indeed, "there is no way to excuse Augustine's treatment of Una" (his concubine) (Wills, 1999: 41). 17

\section{Summa vitae Christianae: Calvin}

Although Paul and Augustine form the main ingredient of Calvin's theology in book 3 of the Institutes $\mathbf{1 8}$ (Lange van Ravenswaay, 1990:111-113), it is intriquing that Calvin nowhere referred to Augustine when he developed his views on the life of a Christian (cf. Mooi, 1965:389) - although the undertones of the views of Augustine are clearly heard. It also is interesting that Calvin in this context nowhere gives an explanation of the Ten Commandments which he treated in book 2.8 of the Institutes where he deals with Christology. This of course does not imply that the commandments of God are irrelevant, but clearly that they should never function as the foundation of Christian life. Calvin's ethic is not legalistic, it is solidly built on the redeeming work of Christ and the renewing work of the Spirit. It is also clear from Calvin's theology that ethics and dogmatics form an inseparable unity.

Another characteristic is Calvin's aversion to philosophical ethics which he estimated inadequate if compared to the wisdom of the Bible. Calvin deals with ethics in book 3 where he explains the work of the Holy Spirit. The section on the Christian life (Inst. 3.6-10) succeeds sections which deal with faith, regeneration and repentance (Inst. 3.2.3). In his Institutes after the section on Christian life Calvin continues with sections on justification by faith (3.9-18), Christian freedom (3.3.19), prayer (3.3.20), election (3.3.21-24) and the final resurrection (3.3.25).

The key features of a Christian life are self-denial, cross-bearing and meditation on the future life - and of course the correct use of the present life. The focus is on a theocentric life, a life of self-denial in

17 The name "Una" is a nickname given by Wills (1999:16), derived from unam habebat. 
the footsteps of Christ, a renewed life through the Holy Spirit and a life in the light of the Word of God. 19

I now turn to the Institutes to give a very brief overview of his ethics. 20

Calvin (Inst. 3.6.1-5) makes it very clear that the life of a Christian can only be described from a biblical perspective, which implies that he is sceptical of an ethics of virtue where we should live "in accordance with nature" (Cicero, Seneca) (Inst. 3.6.3). On the contrary, Christian life receives its strongest motive to God's work through the person and redeeming act of Christ. Christ, who reconciled us with God, "has been set before us as an example, whose pattern we ought to express in our life"; our life must express Christ (Inst. 3.6.3). Furthermore, Christian life is not just a matter of the tongue but of the inmost heart. 21 Doctrine and daily life must go hand in hand.

Calvin does not advocate perfectionism: "I do not so strictly demand evangelical perfection that I would not acknowledge as a Christian one who has not attained it. For thus all of us would be excluded from the church ..." (Inst. 3.6.5). 22 But Christians should always strive and struggle for the goal ahead (namely integrity), which is the opposite of a double face.

Calvin summarises the Christian life as a life of self-denial (Inst. 3.7.1-10), of which cross-bearing forms an integral part (Inst. 3.8.111). He then continues with meditation on the future life (Inst. 3.9.16 ) and concludes with how we must use the present life (Inst. 3.10.1-6).

19 Cf. inter alia the following books on the ethics of Calvin: Lobstein (1877), Harkness (1931), Kolfhaus (1949), Wallace (1961), Gentry (1970), De Klerk (1987), Schulze (1985), Leith (1989). In my booklet (Van Wyk, 1979), I gave summaries of many studies on Calvin's ethics and in another study (Van Wyk, 1983) I tried to give a short overview of his ethics.

For shorter studies on Calvin's ethics, see inter alia: Göhler (1937:299-325), Matheson (1949:48-56), Van Zyl (1964:182-200), Engelbrecht (1988:35-42), Velema (1989:193-222) and Smit (2007a:306-344).

20 I am fully aware of the fact that Calvin's ethics could be developed in a much wider context (cf. Van Wyk, 1983), but for the purpose of this article I focus on the summary Calvin himself has given of the Christian life in his Institutes.

21 This statement is very much Augustinian.

22 Very much Augustinian. 


\subsection{Self-denial}

Self-denial (abnegatio nostri) is a key concept in the ethics of Calvin: self-denial in relation to the world (Inst. 3.7.1-3), self-denial in relation to our fellow humans (Inst. 3.7.4-7) and self-denial in relation to God (Inst. 3.7.8-10). We belong to God and therefore we must direct all the acts of our life to Him, glorifying Him, fleeing the (fashion of the) world. Self-denial consists therefore in obeying the will of God and glorifying Him. According to Titus 2 Christian life consists of a life of sobriety (temperance), righteouness (equity) and godliness (holiness). Self-denial also creates the right attitude towards our fellow humans.

Although there is no explicit refence to Augustine here, his views clearly reverberate in this case. Calvin refers to the fact that each one of us "wishes to tower above the rest", and to the deadly pestilence of pride and self-love. He then mentions 1 Corinthians 4:7, a text so many times quoted by Augustine: "If you have received all things, why do you boast as if they were not given to you?" Therefore Calvin appeals that "whatever man we deal with, we shall treat him not only moderately and modestly but also cordially and as a friend" (Inst. 3.7.4). It is clear that for Calvin self-denial leads to proper helpfulness towards the neighbour; we should seek not our own interest but that of others first.

Love for the neighbour, which includes all persons, does not depend upon the manner of a person, but on the fact that all are created in the image of God. As Christians we should assist every person because we look "upon the image of God in them" (Inst. 3.7.6). Like Augustine, Calvin emphasises that the outward work of love is not sufficient, it is the intention that counts.

Self-denial is also necessary for a good relation to God - it is the "main part". It is for all to see how "uneasy in mind all those persons are who order their lives according to their own plan; we can see how artfully they strive ... to obtain the goal of their ambition or avarice ..." (Inst. 3.7.8). People who live according to their own satisfaction are restless, only those are happy who are blessed by God and who trust in his blessing only. Self-denial also implies that we have to resign ourselves totally to the Lord, that we permit every part of our lives to be governed by God's will. In all things believers must see God's kindness and truly fatherly indulgence. In whatever happens, a believer, "because he will know it ordained of God, will undergo it with a peaceful and grateful mind so as not obstinately to 
resist the command of Him into whose power he once for all surrendered himself and his every possession" (Inst. 3.7.10).

\subsection{Cross-bearing}

An inseparable part of self-denial is found in the idea of crossbearing (tolerantia crucis) (Inst. 3.8.1-11). As followers of Christ we have to take up our cross. Christ has given us an example of patience and we must be conformed to Him. The cross leads us to perfect trust in God's power and grace; it also permits us to experience God's faithfulness and gives us hope for the future; it furthermore trains us to patience and obedience; it prevents us from becoming proud and self-suffient and helps us to stay humble before God. God afflicts us not to ruin or destroy us but to free us from the condemnation of the world.

There are many reasons for suffering, for instance when we defend the (truth of the) gospel or when we in any way maintain the cause of righteousness, but in all circumstances Christians find consolation in God.

Christians experience suffering as sent by God and, unlike the Stoics' insensibility, give expression to their pain and sorrow (Inst. 3.8.9-11). It is not unchristian to groan and weep! There is a big difference between the philosophic and Christian understanding of patience. Nothing happens to believers "except by the will and providence of God. He does nothing except with a well ordered justice" (Inst. 3.8.11). Therefore Christians can always be thankful, joyful and patient.

\subsection{Meditation on the future life}

Another aspect of the Christian life is the meditation on the future life (meditatio futurae vitae) (Inst. 3.9.1-6).

By our tribulations God weans us from excessive love for this present life, because all our actions are worldly. In this regard Calvin does not steer away from - may be too! - strong expressions: we should despise the present life in order to meditate upon eternal life (Inst. 3.9.1-2).

When it comes to comparison with the life to come, the present life can not only be safely neglected but, compared to the former, must be utterly despised and loathed. For, if heaven is our homeland, what else is the earth but our place of exile? (Inst. 3.9.4.) 
"If the earthly life be compared with the heavenly, it is doubtless to be at once despised and trampled underfoot" (Inst. 3.9.4). Calvin even uses Platonic anthropology to clarify his view: "If to be freed from the body is to be released into perfect freedom, what else is the body but a prison?" (Inst. 3.9.4; cf. 3.6.5.) However, the contempt for the present life must not end up in a hatred for it or ingratitude towards God (Inst. 3.9.3/4).

Because to enjoy the presence of God is the summit of all happiness, 23 and in the light of the expectation of eternal life, we can joyfully await the day of death and the final resurrection. "No one has made progress in the school of Christ who does not joyfully await the day of death and final resurrection." (Inst. 3.9.5.)

\subsection{Use of the present life}

Calvin concludes his treatment of the Christian life with a section on how we must use the present life (Inst. 3.10.1-6). He argues that the good things of this life are to be enjoyed as gifts of God. We must try to avoid two dangers: mistaken strictness and mistaken laxity. The main purpose is to use God's gifts for the purpose He created and destined them for us - whether it is clothes, wine, oil, flowers, gold, silver, ivory or marble. We should not use these blessings indulgently or seek wealth greedily, but to serve dutifully in our calling. The fact that God is the Giver of earthly gifts, prevents our narrowmindedness and immoderation. Our expectation of eternal life also determines our conduct in life.

\subsection{Comments}

Calvin's ethics can be characterised as theocentric, Christological, pneumatological, eschatological and Biblical.24 The foundation of Christian life is (faith in) God, the realisation thereof consists of following in the footsteps of Christ through the power of the Holy Spirit on the way to eternal life.

What is striking in Calvin's ethics is his Christological presentation (self-denial and cross-bearing) and eschatological alignment (meditation on future life), all within the context of pneumatology. What is lacking here is an explicit explanation of a key concept, namely love,

24 Cf. Velema (1989:199): "The work of Christ is the foundation of Calvin's ethics." 
which is so central in the biblical teaching. Not that it is totally lacking, because in his explanation of the Ten Commandments Calvin wrote:

We ought to embrace the whole human race without exception in a single feeling of love; here there is no distinction between barbarian and Greek, worthy and unworthy, friend and enemy, since all should be contemplated in God, not in themselves. (Inst. 2.8.55.) ${ }^{25}$

Even in the case of civil government and lawsuit the principle of love stays indispensable (Inst. 4.20.18).

Another question (which Calvin did not clarify) is how one should apply the central notion of self-denial in politics and civil government where self-assertion is the order of the day. We know that Calvin carefully distinguishes between Christ's spiritual kingdom and civil jurisdiction (Inst. 4.20.1), although it is true that the spiritual government of Christ is already initiating in us "certain beginnings" of the heavenly kingdom on earth (Inst. 4.20.2). Thus it is understandable that all human laws must be in conformity "with that perpetual rule of love" (Inst. 4.20.15/18). But how do you realise self-denial and love in a situation of war, even if it is a just war (which Calvin accepted; Inst. 4.20.11)?

I think Calvin goes too far in committing to civil government "the duty of rightly establishing (true) religion" (Inst. 4.20.3/2), because it is not part of the government's task and cannot be applied in cases of a non-Christian government and in multi-religious countries. Theocracy is a confession of faith and not a social ideal to be realised in a sinful world.

\section{Comparison}

As far as the foundation of the Christian life is concerned, both Augustine and Calvin agree that faith in the triune God, as attested in Scripture, provides the final answer. Christian life is a theocentric life. This world and the form of this world is passing away and can never provide happiness, security and rest. Because $\sin 26$ ruins

25 Very much Augustinian.

26 While for Augustine superbia is the origin of sin, for Calvin it is infidelitas (Lange van Ravenswaay, 1990:37). 
individuals and societies, we need the grace of God in Christ and the renewing work of his Spirit to live a meaningful life.

Concerning the realisation of Christian life, Augustine strongly emphasises love as a key feature, while Calvin focuses on the notions of self-denial and cross-bearing. This does not imply that Augustine totally neglected the last two notions, and Calvin the first, but indicates where the emphasis lies for each. 27 Because Augustine views pride as the essence of sin, he could also accentuate the necessity of humility in a good life.

For both the consummation of the Christian life exists in the hope for and expectation of eternal life in the presence of God. Christian life implies not only a life of faith and love but also a life of hope. The way in which both church fathers develop their eschatologies is to a certain extent influenced by Greek philosophy - Augustine by NeoPlatonism and Calvin by Platonism. The consummation of the kingdom is very much a heavenly kingdom in which the dimensions of the renewed earth is underplayed, although not totally lacking. 28 But in the end eschatology makes the world go round. Christians live a life of hope and expectation and are looking forward towards the fulfilment of the great promises of God: the completion of the kingdom of God and the dawn of a new heaven and earth.

\section{Relevance}

I think one could conclude by saying that Augustine and Calvin succeeded in elucidating the essential notions of a Christian life:

- Christian life is not possible without the light of the Word of God.

- Christian life is not possible without putting God in the centre of it: God our Creator, Sustainer, Provider and Source of strength.

- Christian life is not possible without the redeeming and reconciliatory work of Jesus Christ and without following in his footsteps of self-denial and cross-bearing.

27 Calvin remarks that Augustine correctly says that humility is the first, second and third commandment of the Christian religion (Mooi, 1965:238). 
- Christian life is not possible without the renewing and transforming work of the Spirit of God, who teaches us how to live a life of love, humbleness and truth and to reject pride and hatred.

- Christian life is not possible without focusing on the advent of a new heaven and a new earth where God will be all in all.

- Christian life is not possible without faith and hope and love.

- To this we have to add something else.

For centuries Christian ethics focused on individual personal ethics, neglecting to a large extent social ethics. However, the twentieth century represents a turning point in this situation when social ethics receives more attention. ${ }^{29}$ Social ethics is concerned with nuclear war, the worldwide energy, political, economical, and ecological crises; it tries to apply the Christian message of love and humility and self-denial as well as the principles of the kingdom of God to the structures and systems of this overpopulated, damaged, endangered and exhausted world. The world nowadays experiences new challenges of immense proportions. Communism (resp. socialism) collapsed in 1989 and since 2008 (extreme) capitalism finds itself in a severe crisis which asks for new thinking as far as economical systems are concerned. The ecological crisis (environmental pollution, energy exhaustion and global warming) has taken on such extreme proportions that any delay to deal with this problem will be fatal. The biblical notion of caretaking (Gen. 2:15) must be rediscovered and revived.

It is also evident that we are the first (or second) generation with the ability to destroy all life on planet earth several times with nuclear weapons and that therefore the bellum justum theory is outdated and should be replaced by a theology of peace. Christians are called to be the salt of the earth, the light of the world and the yeast of society. Although it will be impossible for them to transform this sinful world into the kingdom of God and the (expected) new earth and heaven, they must try to (re)direct society to that great ideal, they have to penetrate social structures and try to improve and humanise them and in doing so create small signs of the coming kingdom of God. 


\section{List of references}

\section{List of books by Augustine 30}

b. vita: De beata vita (386/987). 1999. Augustinus: over het gelukkige leven. Vert. door R. Ferwerda. Baarn: Agora.

cat. rud.: De catechizandis rudibus (399). 1982. Augustinus: het eerste geloofsonderricht. Vert. door G. Wijdeveld. Baarn: Ambo.

civ. Dei: De civitate Dei (413/427). 1949. The works of Aurelius Augustine, Bishop of Hippo: the city of God. Vol. 1 \& 2. Trans. by M. Dods. Edinburgh: Clark.

conf.: Confessiones (397/401). 2004. St. Augustine: the confessions. Ed. by A.C. Outler. Peabody: Hendrickson.

doc. Chr.: De doctrina Christiana (396; 426/427). 1958. Saint Augustine: on Christian doctrine. Trans. by D.W. Robertson. New York: Macmillan.

ench.: Enchiridion ad laurentium de fide spe et caritate (421/422). 1987. St. Augustine: the Enchiridion on faith, hope and love. Ed. by Paolucci. Washington: Gateway.

ep. Jo.: In epistulam Joannis ad Parthos tractatus (406/407). 1992. Preken over de Eerste Brief van Johannes. Vert. door. T.J. van Bavel. Leuven: Augustinus Historisch Instituut.

mor.: De moribus ecclesiae catholicae et de moribus Manichaeorum (387/388). 1979. Nicene and Post-Nicene fathers of the Christian church. Vol. 4. Ed. by P. Schaff. Grand Rapids: Eerdmans. p. 41-63, 69-89.

reg.: Regula praeceptum (397/399). 1991. Augustinus van Hippo: regel voor de gemeenschap. Vert. door T.J. van Bavel. Kampen: Kok.

retr.: Retractationes (426/427). 1968. Retractations. Trans. by M.I. Bogan. Washington: The Catholic University of America Press.

s. Dom. mon.: De sermone domini in monte (393/395). 2000. Aurelius Augustinus: het huis op de rots. Vert. door L. Wenneker \& H. van Reisen. Amsterdam: Ambo. (Verhandeling over de bergrede.)

sermo-a. 1-32. 1996. Augustinus: commentaar op Psalm 118/119. Vert. door T.J. van Bavel. Baarn: Ambo.

sermo-b. 113. 2002. Als korrels tussen kaf: preken over teksten uit het Marcusen Lucasevangelie. Vert. door J. Gehlen-Springorum, et al. Amsterdam: Ambo.

sermo-c. 150. 1988. Augustinus: Carthaagse preken. Vert. door G. Wijdeveld. Baarn: Ambo.

sermo-d. 198. 2001. Aurelius Augustinus: als lopend vuur: preken voor het liturgisch jaar 2. Vert. door R. van Zaalen, H. van Reisen \& S. van der Meijs. Amsterdam: Ambo.

trin.: De Trinitate (399-422/426). 1997. Saint Augustine: the Trinity. Trans. by E. Hill. New York: New City Press.

30 For the sake of clarity and simplicity I refer to the books of Augustine in the following way: first the Latin abbreviation, followed by the full title in Latin (with the date of publication). Then follows the information of a translation of that book. 


\section{List of other books 31}

BABCOCK, W.S., ed. 1991. The ethics of Augustine. Atlanta: Scholars Press. BIGHAM, T.J. \& MOLLEGEN, A.T. 1955. The Christian ethic. (In Battenhouse, R.W., ed. A companion to the study of St. Augustine. New York: Oxford University Press. p. 371-397.)

BURCHILL-LIMB, K.Y. 2006. The actuality of Augustine's distinction between uti and frui. Augustiniana, 56:183-197.

BURNABY, J. 1938. Amor Dei: a study of the religion of St. Augustine. London: Hodder \& Stoughton.

BURNS, J.P. 1991. Augustine on the origin and process of evil. (In Babcock, W.S., ed. 1991. The ethics of Augustine. Atlanta: Scholars Press. p. 6785.)

CALVIN, J. 1960. Institutes of the Christian religion. 2 vol. Trans. by F.L. Battles. London: Westminster John Knox.

CARNEY, F.S. 1991. The structure of Augustine's ethic. (In Babcock, W.S., ed. The ethics of St. Augustine. Atlanta: Scholars Press. p. 11-37.)

COUVEE, P.J. 1947. Vita beata en vita aeterna: een onderzoek naar de ontwikkeling van het begrip "vita beata" naast en tegenover "vita aeterna", bij Lactantius, Ambrosius en Augustinus, onder invloed van Romeinsche Stoa. Baarn: Hollandia.

DE KLERK, P., ed. 1987. Calvin and Christian ethics. Grand Rapids: Calvin Studies Society.

ENGELBRECHT, B. 1988. Die etiek van Calvyn. (In Wethmar, C.J. \& Vos, C.J.A., reds. 'n Woord op sy tyd: 'n teologiese feesbundel aangebied aan Professor Johan Heyns ter herdenking van sy 60e verjaarsdag. Pretoria: NG Kerkboekhandel. p. 35-42.)

FREND, W.H.C. 1952. The Donatist church: a movement of protest in Roman North Africa. Oxford: Clarendon.

GALVAO, H. DE N. 1986-1994. Beatitudo. (In Mayer, C., ed. AugustinusLexikon. Vol. 1. Basel: Schwabe. p. 624-638.)

GENTRY, W.C. 1970. A study of John Calvin's understanding of moral obligation and moral norms in Christian ethics. Michigan: Arbor.

GILSON, E. 1960. The Christian philosophy of Saint Augustine. New York: Random.

GÖHLER, A. 1937. Das Christliche Leben nach Calvin. Evangelische Theologie, 4:299-325.

HAN, S.J. 2008. An investigation into Calvin's use of Augustine. (In Prompte en sincere: Johannes Calvyn en die uitleg van die Woord van God. Aca theologica, supplementum, 10:70-83.)

HARKNESS, G. 1931. John Calvin: the man and his ethics. New York: Holt.

HOLMES, R.L. 1999. St. Augustine on the just war theory. (In Matthews, G.B., ed. The Augustian tradition. London: University of California Press. p. 323344.)

31 Researchers also draw attention to the following studies:

ARMAS, G. 1955. La moral de san Agustin. Madrid: Asilo de Huérfanos.

ROLAND-GOSSELIN, B. 1925. La morale de saint Augustin. Paris: Riviére. 
KENT, B. 2001. Augustine's ethics. (In Stump, E. \& Kretzmann, eds. The Cambridge companion to Augustine. Cambridge: Cambridge University Press. p. 205-233.)

KOLFHAUS, W. 1949. Vom Christlichen Leben nach Johannes Calvin. Neukirchen: Kreis Moers.

KÜNG, H. 1991. Global responsibility: in search of a new world ethic. London: SCM.

KÜNG, H. 1995. Christianity: its essence and history. London: SCM.

KÜNG, H. 1997. A global ethic for global politics and economics. London: SCM. LANCEL, S. 2002. St. Augustine. London: SCM.

LANE, A.N.S. 1999. John Calvin: student of the church fathers. Edinburgh: Clark.

LANGAN, J. 1991. The elements of St. Augustine's just war theory. (In Babcock, W.S., ed. 1991. The ethics of Augustine. Atlanta: Scholars Press. p. 168-189.)

LANGE VAN RAVENSWAAY, J.M.J. 1990. Augustinus totus noster: das Augustin-Verständnis bei Johannes Calvin. Göttingen: Vandenhoeck \& Ruprecht.

LAVERRE, G.J. 1999. Virtue. (In Fitzgerald, A.D., ed. Augustine through the ages: an encyclopedia. Grand Rapids: Eerdmans. p. 871-874.)

LEITH, J.H. 1989. John Calvin's doctrine of the Christian life. Louisville: WJK.

LOBSTEIN. P. 1877. Die Ethik Calvins in ihrem Grundzügen entworfen: ein Beitrag zur Geschichte der Christlicher Ethik. Strassburg: Schmidt's Universitäts-Buchhandlung.

MARKUS, R.A. 1988. Saeculum: history and society in the theology of St. Augustine. Cambridge: Cambridge University Press.

MARROU, H-I. 1981. Augustinus und das Ende der antiken Bildung. Paderborn: Schöningh.

MATHESON, J.G. 1949. Calvin's doctrine of the Christian life. Scottish journal of theology, 2:48-56.

MAUSBACH, J. 1909. Die Ethik des heiligen Augustinus. Bd. 1 \& 2. Freiburg im Bresgau: Herder.

MAYER, C. 2006. Humiliatio, humilitas. (In Mayer, C., ed. Augustinus-Lexikon. Vol. 3., fasc. 3/4. Basel: Schwabe. p. 443-456.)

MOOI, R.J. 1965. Het kerk- en dogmahistorisch element in de werken van Johannes Calvijn. Wageningen: Veenman.

NÜRNBERGER, K. 1999. Prosperity, poverty \& pollution: managing the approaching crisis. Pietermaritzburg: Cluster.

O'DONNELL, J.J. 2005. Augustine, saint and sinner: a new biography. London: Profile Books.

O'DONOVAN, O. 2003. The just war revisited. Cambridge: Cambridge University Press.

PEETERS. M.A. 2006. The new global ethics: challenges for the church. Brussels: Institute for Intercultural Dialogue Dynamics.

POSSIDIUS, 1988. The life of Saint Augustine. Trans. by J.E. Rotelle. Villanova: Augustinian Press.

REUL, A. 1928. Die sittlichen Ideale des heiligen Augustinus. Paderborn: Schöningh.

RIST, J.M. 1999. Augustine: ancient thought baptized. Cambridge: Cambridge University Press. 
ROLAND-GOSSELIN, B. 1930. St. Augustine's system of morals. (In D'Arcy, M.C. A monument to St. Augustine: essays on some aspects of his thought written in commemoration of his 15th centenary. New York: MacVeagh. p. 225-248.)

SCHAFFNER, O. 1959. Christliche Demut: des hl. Augustinus Lehre vor der Humilitas. Würzburg: Augustinus Verlag.

SCHLABACH, G.W. \& FITZGERALD, A.D. 1999. Ethics. (In Fitzgerald, A.D., ed. Augustine through the ages: an encyclopedia. Grand Rapids: Eerdmans. p. 320-330.)

SCHULZE, L.F. 1985. Calvin and "social ethics": his views on property, interest and usury. Pretoria: Kital.

SMIT, D.J. 2007a. Views on Calvin's ethics: reading Calvin in the South African context. Reformed world, 4:306-344.

SMIT, D.J. 2007b. Essays in public theology: collected essays. Vol. 1. Stellenbosch: Sun Press.

STOTT, J. 1990. Issues facing Christians today: new perspectives on social and moral dilemmas. London: Pickering.

STUDER, B. 2006. Veritas Dei in der Theologie des heligen Augustinus. Augustinianum, 46:411-455.

SWITALSKI, B. 1946. Neoplatonism and the ethics of St. Augustine. New York: Polish Institute of Arts and Sciences in America.

TESELLE, E. 1970. Augustine the theologian. London: Burns \& Oats.

TESELLE. E. 1991. Towards an Augustinian politics. (In Babcock, W.S., ed. The ethics of Augustine. Atlanta: Scholars Press. p. 147-168.)

TORCHIA, N.J. 1993. The significance of Ordo in St. Augustine's moral theory. (In Lienhard, J.T., Muller, E.C. \& Teske, R.J., eds. Augustine: presbyter factus sum. New York: Lang. p. 263-276.)

VAN BAVEL, T.J. 1970. Augustinus: van liefde en vriendschap. Baarn: Het Wereldvenster.

VAN DER MEER, F. 1949. Augustinus de zielzorger: een studie over de praktijk van een kerkvader. Utrecht: Het Spectrum.

VAN WYK, J.H. 1979. Die etiek van Calvyn. Potchefstroom: Instituut vir die Bevordering van Calvinisme.

VAN WYK, J.H. 1983. Calvyn oor die Christelike lewe. Pretoria: NG Kerkboekhandel.

VAN WYK, J.H. 1984. Etiek van vrede: 'n teologies-etiese evaluering van die Christenpasifisme. Stellenbosch: Cabo.

VAN WYK, J.H. 2001a. Etiek en eksistensie in koninkryksperspektief. Potchefstroom: Potchefstroomse Teologiese Publikasies.

VAN WYK, J.H. 2001b. John Calvin on the kingdom of God and eschatology. In die Skriflig, 36(2):191-205.

VAN WYK, J.H. 2002a. Venialis culpa? Augustinus oor huwelik en seksualiteit. In die Skriflig, 36(3):327-348.

VAN WYK, J.H. 2002b. Faith, ethnicity and contextuality: an investigation of their relation and relevance to church and Christianship. (In Van der Borght, A.J.G., Van Keulen, D. \& Brinkman, M., eds. Studies in reformed theology: faith and ethnicity. Vol. 2. Zoetermeer: Meinema. p. 22-46.)

VAN ZYL, A.H. 1964. Calvyn oor die Christelike lewe. Nederduitse Gereformeerde teologiese tydskrif, 3:182-200.

VELEMA, W.H. 1989. Ethiek bij Calvijn. (In Borgers, D.H. Reformatorische stemmen - verleden en heden. Apeldoorn: Zwijgerstichting. p. 193-222.) 
VILLA-VICENCIO, C. \& DE GRUCHY, J., eds. 1994. Doing ethics in context: South African perspectives. Claremont: Philip.

WALLACE, R.S. 1961. Calvin's doctrine of the Christian life. Grand Rapids: Eerdmans.

WETZEL, J. 1992. Augustine and the limits of virtue. Cambridge: Cambridge University Press.

WILLIAMS, D.D. 1955. The significance of St. Augustine today. (In Battenhouse, R.W., ed. A companion to the study of St. Augustine. New York: Oxford University Press. p. 3-14.)

WILLS, G. 1999. Saint Augustine: a penquin life. New York: Viking Penquin.

\section{Key concepts:}

Christian life

cross-bearing

happiness

humility

love

meditation

self-denial

truth

Kernbegrippe:

Christelike lewe

gelukkigheid

kruisdra

liefde

meditasie

nederigheid

selfverloëning

waarheid 
What are the key characteristics of a Christian life? A comparison of the ethics ... 